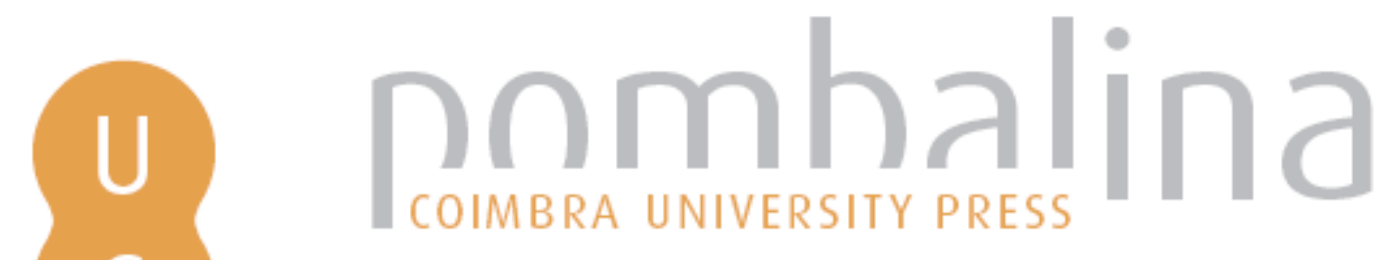

Nemésio e Antero

Autor(es): $\quad$ Pires, António M. B. Machado

Publicado por: Imprensa da Universidade de Coimbra

URL

persistente: URI:http://hdl.handle.net/10316.2/38682

DOI: $\quad$ DOI:http://dx.doi.org/10.14195/978-989-26-1164-8_5

Accessed : $\quad$ 26-Apr-2023 14:56:04

A navegação consulta e descarregamento dos títulos inseridos nas Bibliotecas Digitais UC Digitalis, UC Pombalina e UC Impactum, pressupõem a aceitação plena e sem reservas dos Termos e Condições de Uso destas Bibliotecas Digitais, disponíveis em https://digitalis.uc.pt/pt-pt/termos.

Conforme exposto nos referidos Termos e Condições de Uso, o descarregamento de títulos de acesso restrito requer uma licença válida de autorização devendo o utilizador aceder ao(s) documento(s) a partir de um endereço de IP da instituição detentora da supramencionada licença.

Ao utilizador é apenas permitido o descarregamento para uso pessoal, pelo que o emprego do(s) título(s) descarregado(s) para outro fim, designadamente comercial, carece de autorização do respetivo autor ou editor da obra.

Na medida em que todas as obras da UC Digitalis se encontram protegidas pelo Código do Direito de Autor e Direitos Conexos e demais legislação aplicável, toda a cópia, parcial ou total, deste documento, nos casos em que é legalmente admitida, deverá conter ou fazer-se acompanhar por este aviso.

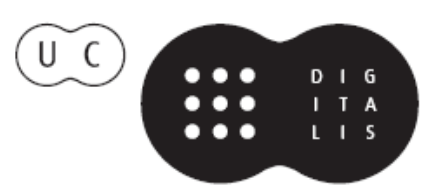


António M. B. Machado Pires

Universidade dos Açores

\section{NEMÉSIO E ANTERO}

Em 1932, Vitorino Nemésio incluía, nos ensaios de Sob os Signos de Agora ${ }^{1}$, um capítulo intitulado "O Monge", subdivisão de uma parte do livro, "O Marrano, o Solitário, o Monge e o Pessimista". O texto pode ficar um tanto perdido num livro de conteúdo tão diversificado. Mas esse texto é, afinal, o artigo de fundo publicado cerca de três anos antes no Diário de Lisboa, em 17 de abril de 1929, então com o título "Antero". Em véspera do aniversário do nascimento de Antero de Quental (fazia 87 anos) ia inaugurar-se um monumento no Jardim da Estrela e Joaquim Manso, o diretor do jornal, iria fazer uma conferência sobre Antero no dia 18, conforme anunciado no jornal de 17.

O artigo de Nemésio, que enche a $1^{a}$ página, é significativo, principalmente porque exorta a que se repare na abrangência, na universalidade e na qualidade filosófica e literária da obra de Antero, que continua a chamar a atenção mais pelo impacto das circunstâncias do suicídio. Sem ironia, Nemésio acha que é caso para se dizer: Antero, suicídio; Camões, o olho!

Assim como a falta de um olho em Camões nos preocupou em demasia, o suicídio de Antero ficou sendo o primeiro plano na perspectiva do seu vulto. Fez-se do suicídio de Antero um caso de great atraction (...).

Ora Antero, lido, admirado e citado por tantos e tais como Miguel de Unamuno, é um símbolo de universalidade e orgulho de uma cultura.

\footnotetext{
1 Sob os Signos de Agora, $1^{\mathrm{a}}$ edição, Lisboa, Bertrand, 1932. $2^{\mathrm{a}}$ edição, Lisboa, Imprensa Nacional / Casa da Moeda, 1995 (Introdução de José Martins Garcia).
} 
Ainda hoje se pode dizer que o autor dos Sonetos, o "Príncipe da Mocidade", o dinamizador das Conferências do Casino, o autor das Tendências Gerais da Filosofia na $2^{a}$ Metade do Século xIX, o "santo Antero", o íntegro Antero, continua a ser principalmente visto como o suicida do Campo de S. Francisco, encarado de modo "emblemático" e mostrado aos turistas... Orgulho de intelectualidade filosófica e poética para uns, os poucos que o sabem ler -, curiosidade para outros...

Em 1929, o jovem Nemésio tem apenas 28 anos e demonstra já uma notável erudição em volta da figura e da repercussão que deve merecer Antero. Esta página anteriana de Nemésio no Diário de Lisboa é do melhor de Nemésio cronista. Pelo conteúdo, pelo estilo e pela cultura geral evidenciada. De resto, Sob os Signos de Agora reúne ensaios e intervenções diversas, que ele achou dignas de serem reunidas num livro de ensaios contemporâneo do seu Doutoramento sobre Herculano. Sob a exortação do Prof. Joaquim de Carvalho, diz-nos Nemésio, havia que dar a conhecer uma nova geração de ensaístas, com cerca de 30 anos de idade (Nemésio tem 31 quando o livro se publica e 28 quando escreveu a citada página sobre Antero). Era já um escritor conhecido. Destaque-se que recentemente publicara o romance Varanda de Pilatos (1927).

No fim do Prefácio a Sob os Signos de Agora Nemésio escreveu:

Casualmente escrito ao escoar do último grão dos meus trinta anos, este prefácio a um livro que não chega a ser coisa alguma verte melancolia. Se eu chegar a ser alguma coisa, o melhor de mim será a consciência um tanto severa do que poderia ter sido, teimosamente ligado à saudade e ao amor do que deixei.

É assinado em Coimbra, Cruz de Celas, Quinta das Albergarias, 19 de dezembro de 1931 - isto é, dia do seu aniversário dos 30 anos.

Ora neste livro de ensaios de Nemésio vem também um texto que resulta de uma conferência de 1928 na Associação Académica de Coimbra, num plano de "reabilitações regionais" que até vinha permitir-lhe falar dos seus sempre saudosos Açores: "O Açoriano e os Açores". Aí fala do caso de um homem subtraído à sua ilha, mas que "sob o poder sugestivo de uma civilização enérgica" (...) "enriqueceu o temperamento que se lhe talhou na terra a ponto de chegar aos 
mais altos resultados de pensamento e de conduta. Para os Açores esse homem foi Antero."

O jovem Nemésio insiste na universalidade de Antero:

“(...) o essencial neste mundo é ganhar as asas que nos libertem da temporalidade e da matéria. Antero compreendeu-o. Por seu intermédio, os Açores partilharam das mais graves e nobres inquietações da Europa contemporânea." E acrescenta: (...) a universalidade do seu espírito não se compadecia com este apego à terra que o destino reserva às almas mais terrenas.” E a propósito da relação do mar com o sentimento de liberdade anteriano, tem uma das suas mais belas frases sobre a condição insular que ele experimentava de forma única: (Para o ilhéu) "O mar é não só o seu conduto terreal como o seu conduto anímico. As ilhas são o efémero e o contingente: só o mar é eterno e necessário." ${ }^{2}$

Vem tudo isto a propósito de como Nemésio teve em mente o "caso" Antero, até às últimas aulas que lhe ouvi.

Como se sabe, o primeiro diagnóstico escrito é o longo artigo de Sousa Martins, "Nosografia de Antero", publicado no In Memoriam (1896). Nemésio referia-se-lhe nas aulas como uma hipertrofia retórica, uma interpretação que mais fazia lembrar uma "conspiração de células" (sic!) que engendraram um degenerado superior. Os conceitos de "degenerado" e de "degenerescência" andavam muito em moda nos finais do século xix, depois dos escritos do famoso Max Nordau (lembre-se o livro, em tradução francesa, Dégenéréscence, Paris, 1894). O conceito aplicava-se também aos artistas (simbolistas e decadentistas incluídos). José Coelho Moreira Nunes apresentou como tese de Medicina (Porto, 1899) um trabalho intitulado O Simbolismo como Manifestação da Degenerescência (note-se a abrangência imputada ao fenómeno: da degenerescência e não de degenerescência!). As casas reais, as manias (como a melomania de D. João V) eram objeto de interpretação à luz da degenerescência (veja-se Ramalho Ortigão, As Farpas, maio de 1886).

2 Sob os Signos de Agora, "O Açoriano e os Açores", 2a edição, Lisboa, Imprensa Nacional/Casa da Moeda, 1995, pp. 100-101. 
A ciência médica, por forte influência do Positivismo, meteu-se a "explicar" o génio e arte. No caso de Antero, a "conspiração de células" não explica nada, mas dá conta de um problema que preocupou uma geração de amigos e as gerações seguintes, até ao nosso tempo. Ficou bem conhecido o ponto de vista de Miller Guerra, segundo o qual Antero teria sofrido de psicose maníaco-depressiva, hoje talvez se chamasse doença bipolar... Apolíneo e dionisíaco, luz e trevas são também dois "polos" anterianos, segundo António Sérgio.

Aquando do centenário da morte, em 1991, a Universidade dos Açores organizou um Congresso Anteriano Internacional e, para se fazer um ponto de situação, convidaram-se (além de Miller Guerra, que já não pôde vir), os psiquiatras Formigal Luzes e Dias Cordeiro, que deixaram os seus pontos de vista publicados nas Atas do Congresso ${ }^{3}$. Recentemente, Joana Amaral Dias, psicóloga clínica, publicou o livro Maníacos de Qualidade, em que inclui um capítulo sobre Antero. É um exercício de automemorialismo ficcional, fazendo Antero contar a sua "história", que não perde de vista a célebre carta autobiográfica a W. Storck (escrita em 1887, com 45 anos).

Este "caso" Antero, como o "caso" Pessoa, são a prova de que a necessidade de "explicação" das relações génio-obra, à luz da Ciência, é uma componente respeitável da curiosidade humana e transforma-se num fenómeno de cultura. O Homem é um ser total, biológico-intelectual. Não sei porque é que um poema não possa ser tomado também como um fenómeno de base biológica e neuropsíquica. Todos sabemos que as nossas reacções, sentimentos e volições se modificam em função de pequeníssimas mas potentes segregações hormonais. O que se não deve é reduzir, por uma superstição positivista, a criatividade a explicações funcionais, esquecendo que a matéria é animada por um espírito e por um destino imprevisível. Só há verdadeiramente admiração pela Ciência quando há admiração pelo espírito criador. O resto é materialismo grosseiro.

Quando Nemésio diz, no citado artigo de 17 de abril de 1929, que o suicídio de Antero está transformado em "great attraction" em detrimento da sua verdadeira significação, está a tocar o cerne da questão. Mas para a boa compreensão do facto humano e cultural é preciso ler poesia, saber filosofia e entender a época.

3 Congresso Anteriano Internacional, Actas, Ponta Delgada, Universidade dos Açores, 1991. 
Como Unamuno dizia de Espinosa, a quem le dolia Diós, a Antero também "lhe doía Deus" e a Humanidade. Diz Nemésio:

É pensar com o espírito e não só com a razão (..) — mas com alguma coisa em que se integram esses dois hemisférios do ser. Assim fez Antero, colocado pelo mesmo Unamuno no plano de Santo Agostinho e de Pascal, de Kierkegard e Leopardi. E porque o fez, têm-no entendido muito poucos.

A dificuldade ao abeirarmo-nos deste homem genial reside na contradição aparente do seu espírito, tão depressa elevado à severa região das ideias como abatido ao abismo enegrecido dos desesperos.

A incompreensão perante a obra de Antero - explica ainda Nemésio - está no preconceito da abordagem, que exige a definição de um Antero ou pessimista ou otimista. Ora na maioria os Sonetos são "dores de um espírito que pensou", "expressão poética de uma mensagem espiritual".

O que Antero confirma, quando fala da sua poesia na carta autobiográfica a Storck, a propósito do volume dos Sonetos:

Estimo este livrinho dos Sonetos por acompanhar como a notação dum diário íntimo e sem mais preocupações do que a exactidão das notas de diário, as fases sucessivas da minha vida intelectual e sentimental. Ele forma uma espécie de autobiografia de um pensamento e como que as memórias de uma consciência.

E no Natal de 1885, em carta de 24 de dezembro a Jaime Batalha Reis, falara mesmo na necessidade de "matar" o poeta que em si havia, pois afinal ... a poesia é a sua doença, a doença de pensar! "Vou bastante melhor, ainda que de cabeça menos, mas espero vencer também isso com método, tempo e paciência. Empreendi, só com a força da vontade e da razão, não só curar uma nevrose, mas transformar um temperamento. É difícil, mas não impossível, e creio que alguma coisa levo já alcançada. Este processo implicava uma morte violenta: a do poeta que em mim havia.” A "doença”, do espírito ou do corpo, está em relação com o processo poético, é condicionante do mesmo. E isto não é passível de

4 Antero de Quental, Cartas. Leitura, organização, prefácio e notas de Ana Maria Almeida Martins, $2^{a}$ edição, Lisboa, Imprensa Nacional/Casa da Moeda, 2009, vol.II, p. 494. 
uma só curiosidade médica ou de criação de diagnósticos, mas de um processo biológico-cultural que engloba o Homem como um todo. Afinal, a "conspiração de células" ultrapassa o diletantismo e a retórica da diagnose de Sousa Martins!

De resto, a ideia de que Antero é "indispensável” à compreensão da cultura oitocentista em Portugal está patente numa crónica do Diário de Lisboa de 13 de julho de 1935 quando Nemésio diz que um lado da alma portuguesa está em Camilo, outro lado tem como "chaves” indispensáveis Garrett, Herculano, Antero e Eça.

Nemésio - João Garcia, esse disfarce autocaracterológico, tem no seu quarto um retrato de Antero... Mau Tempo no Canal é um romance empenhado em dar grandes referências dos Açores, obra em que cita Gaspar Frutuoso, Antero de Quental e Francisco de Lacerda.

Nemésio aproveitou vários pretextos para falar da exemplaridade de Antero. Inclusive nos "programas" escolares que lhe conheci. Nos últimos anos de regência da cadeira de História da Cultura Portuguesa escolheu, em dois programas de anos sucessivos, uma rubrica que fala por si:

"Herculano e Antero como índices do pensamento do seu tempo."

A Herculano pedia a exemplaridade do seu temperamento forte e o conhecimento da Idade Média em que nascera a nacionalidade portuguesa, sem esquecer a abundante erudição que tinha sobre o Liberalismo.

A Antero interessava-lhe apontar o grande exemplo de universalidade, de luta pela Justiça, de intervenção num momento cultural decisivo como o das Conferências do Casino. Foi assim que o seu Assistente "herdou" uma sugestão para erigir em tema de doutoramento a ideia de decadência nacional alargada à geração de 70 .

Instituída pela reforma que criou os cursos de Filologia em 1959, a cadeira de História da Cultura Portuguesa era de opção para Filologia Românica, obrigatória para os cursos de História ( $5^{\circ}$ ano), Filosofia ( $3^{\circ}$ ano) e Filologia Germânica ( $2^{\circ}$ ano). Era pois diferente falar de Antero em aulas teóricas para alunos tão diversos e em diversas idades, reunidos num anfiteatro. A abordagem tinha de ser relativamente generalista, mas Nemésio punha a tónica no "Antero social" e 
nas Conferências do Casino, analisando as "Causas de Decadência dos Povos Peninsulares", chamando atenção para o "plural hispânico" e para o facto de Antero ser ainda um jovem de 29 anos impulsionado por emoções vivas. Um texto discutível mas muito notável, que, como diz Eduardo Lourenço, abria o caminho da modernidade.

O Antero das "Causas de Decadência..." merecia mais espaço de reflexão numa cadeira de História da Cultura do que o Antero literário, da Questão Coimbrã ou dos Sonetos. Era assim que Nemésio o abordava nos últimos anos do seu magistério.

Tanto a obra de Nemésio como a de Antero, por valências diferentes e muito específicas, ficam de referência na Cultura Portuguesa. A nós, nos Açores, cabe-nos a obrigação de reconhecer que a universalidade se conquista não só pelo toque de génio mas por condições objetivas de mundo e cosmopolitismo. Antero saiu definitivamente da sua citada "província remota imersa num plácido sono histórico"; Nemésio havia de lembrar sempre o microcosmos da Ilha matricial porque viveu fora dela. Curioso que ambos quiseram ou sonharam regressar: um para, desiludido, acabar numa decisão fatal; o outro, prometendo, aos 31 anos, que um dia, com a vida civil cumprida, haveria de regressar e escrever um ensaio sobre a sua açorianidade, e aí inventou a palavra-chave!

O que cada um deles fez, não fez o outro. Não se podem comparar.

A um cabe a olímpica universalidade da busca metafísica, ao outro o canto da alma telúrica da sua Ilha e das gentes que nela habitam. A um, a saudade de Deus na descida aos infernos do eu; ao outro, a viagem no eu saudoso da infância, com Deus espreitando o caminhante.

A emulação Nemésio - Antero será só de natureza mítica, como afirma Eduardo Lourenço num excelente ensaio de A Noite Intacta 5 . Ambos se defrontaram perante um mar diversamente condicionador do eu poético e ontológico, que em Antero sugere a Liberdade, em Nemésio é fons et origo, o mar mais importante do que a terra, pois que a define, a delimita, eterno e necessário.

Nemésio e Antero são dois vultos emblemáticos: casos únicos, na unicidade que o grande talento ou o toque do génio individualizam. Diferentes, porém, a

5 Eduardo Lourenço, A Noite Intacta. Centro de Estudos Anterianos, Vila do Conde, 2000, "Antero e o imaginário nemesiano", pp. 151-166. 
ambos o toque da asa da transcendência deu comportamentos diferentes - num a angústia metafísica rompeu as barreiras psíquicas da resistência; no outro a mística da saudade da Ilha cruzou-se com a recuperação da Fé, qual filho pródigo que viaja agostinianamente até à porta de Deus:

(...)

Paro à porta de Deus e choro

Paro à porta de Deus e choro só. ${ }^{6}$

Afinal ambos poetas do Sagrado, com mais ou menos ilha lá dentro...

6 Poema "O Cavalo Sidério", in Limite de Idade. Lisboa, 1972. 